\title{
The Impediments to Student Engagement: A hybrid Method Based on Fuzzy Delphi and Fuzzy DEMATEL
}

\author{
Andrea Aria ${ }^{1, *}$, Parivash Jafari ${ }^{2} \&$ Maryam Behifar ${ }^{2}$ \\ ${ }^{1}$ CIS Department, Robinson College of Business, Georgia State University, 35 Broad St NW, Atlanta, GA 30303, \\ USA \\ ${ }^{2}$ School of Management and Economics, Department of Educational Administration, Islamic Azad University, \\ University, Science and Research Branch, Tehran, Iran \\ *Corresponding author: CIS Department, Robinson College of Business, Georgia State University, 35 Broad St NW, \\ Atlanta, GA 30303, USA. Tel: 1-404-702-6019. E-mail: aaria@gsu.edu
}

Received: May 24, 2020

Accepted: July 23, $2020 \quad$ Online Published: October 14, 2020

doi:10.5430/wje.v10n5p45

URL: https://doi.org/10.5430/wje.v10n5p45

\begin{abstract}
Student engagement is one of the most important determinants of learning outcomes in higher education institutions. This paper focuses on impediments to student engagement. The Fuzzy Delphi technique was used to screen and elicit important impediments. Four main criteria (individual, family, institution, and environment) and Twenty three sub-criteria were selected by experts through the fuzzy Delphi technique. The fuzzy DEMATEL technique was used to determine the causal relationships among the criteria (impediments). Findings showed that institutional, environmental, and family factors were in the cause group, individual, and family factors were in the effect group. Among the 23 sub-factors, eleven factors were in the cause group and twelve factors were in the effect group. The first three influencing factors were: teachers' poor quality of teaching, inadequate facilities of classroom and institution, and non-applicable materials and curriculum. The first three influenced factors were: poor quality of the relationship between teachers and students, financial problems and high tuition fees, and decreasing the value and status of education in the society.
\end{abstract}

Keywords: student engagement, impediments, fuzzy Delphi, fuzzy DEMATEL

\section{Introduction}

Today, universities are regarded as the most important institutions for creating human capital. They are considered as the engine of development of countries around the globe. The effectiveness of universities and their outcomes are influenced by the quality of students' learning and their educational success. Numerous factors affect educational success and students' learning quality. One of these factors is student academic engagement. It not also leads to a high level of learning outcome but also results in decreases in depression, substance abuse, delinquency (Li and Lerner, 2011). Student engagement would bring about positive consequences for individuals, institutions, and society as well. Considering the positive outcomes of student engagement, it has been a subject of extensive studies for recent decades. We can divide such studies into four general categories: the studies on what (nature), why (forces and sources), how, and what effects (consequences). While there is relative agreement about the outcome and consequences of student engagement, but we face numerous and diverse views on the what, why, and how of student engagement. This indicates the complex and multi-faceted nature of this construct.

Since introducing the construct of student engagement, researchers have tried so much to conceptualize it. The result of such efforts has been the presentation of numerous definitions. Some focusing on constituent elements and components; some on the influential factors; some on how, and others on consequences, or combination of the above. Such an approach towards student engagement and lack of boundary clarity between antecedents, procedures, and consequences have brought about difficulties for policy and practice in addition to creating ambiguities for the next researchers. Kuh (2001), in his definition, mostly emphasizes the role of universities in utilizing resources, designing curriculum and other learning opportunities, as well as providing support services for motivating students to participate in educational activities and achieving experiences and desirable learning outcomes such as perseverance, 
satisfaction, learning, and graduation. Salanova, Schaufeli, Martínez, \& Bresó (2010) mostly highlight the role of students, such as intrinsic motivation for focusing on learning, attending the classes, taking part in educational activities, showing curiosity, posing questions, and enjoying learning challenges, immersing in learning and studying with full energy. Trowler (2010), by summing up the existing literature, has focused on both aspects (student and institution) and defined student engagement as spending time, energy, and efforts on the part of students and higher education institutions to optimize students' experiences, enhance learning outcomes and institution's reputation.

One of the most accepted definitions is a tripartite framework in which Fredricks, Blumenfeld, and Paris (2004) have defined engagement in three dimensions of cognitive, psychological, and behavioral. The behavioral aspect points to participation, making efforts, paying attention, hardworking, positive behavior, and lack of disruptive behaviors (Connell, 1990; Finn, 1989; Finn \& Rock, 1997 cited in Fredricks, Filsecker, \& Lawson, 2016). The psychological dimension refers to the extent of positive and negative reactions to the teacher, classmates, and staff, sense of belonging to the institution, and identification with it (Finn, 1989; Voelkl, 1997 cited in Fredricks et al., 2016). Finally, the cognitive dimension has been defined as self-regulated learning, employing deep learning methods, and making efforts for understanding complex concepts (Feredricks et al., 2004; Pintrich \& De Groot, 1990, Zimmerman, 1990, cited in Fredricks et al., 2016)

Based on the above definitions, engaged students are enthusiastically and diligently involved in their academic duties, spend too much time, energy, and efforts to learn and enhance the required competencies for stepping into the social and professional life as well as meeting the society's needs and expectations. However, the evidence indicates the decline and even lack of engagement among university students. Due to various reasons, they experience academic burn out, lack of motivation, and lack of engagement during their studies which cause numerous problems for the individual and society. Therefore, the main question is: "Why do enthusiastic students lose their eagerness and engagement after entering college?" Finding the answer to this question is one of the main concerns of higher-education policy-makers and researchers.

The amount of effort, energy, and time a person spends on learning activities can be explained by the expectancy-value theory. According to this theory, what one chooses to do about success, performance, and perseverance is a function of his expectations of success in those tasks as well as the value of success (Eccles, 2011; Wigfield, 1994). This means that personal values and expectations determine his behaviors and choices. This theory consists of four components: attainment value (the value of doing a thing well); innate value (the pleasure of being involved in a particular activity or the pleasure one expects to get from doing something); usefulness value (the usefulness of an activity or the extent the of appropriateness of doing a job with one's future goals and plans, such as career goals); and proportional expenses (whatever the person loses while involving in a specific activity such as making efforts for achieving success which results in losing time for other valuable affairs, or the psychological cost and psychological breakdown of a failure) (Eccles, 2005). According to this theory, the person would regulate his/her extent of energy, efforts, and commitment based upon his/her perception of various activities' significance, usefulness, or the expenses of those activities. Each individual's expectations and values are influenced by personal factors (such as self-efficacy beliefs, the difficulty of activities, and the person's goals and experiences), as well as cultural and social factors (Eccles, 2007, 2011).

A lot of researches has been conducted about the fundamental reasons for engagement or lack of engagement. However, most of them refer to teaching characteristics (Jang, Reeve, \& Deci, 2010), the communication and interaction between the students and teachers, the structural features of the class (Benner, Graham, \& Mistry, 2008), type of tasks (Marks, 2000), the role of the family, teacher and classmates (Stipek 2002, Wang \& Eccles, 2013), and factors related to students and institutions. Some researchers (Lawson \& Lawson, 2013 cited in Zepke, 2019, Mann, 2001 cited in Kahu, 2013, Zepke, Leach, \& Butler, 2010) also included the social-cultural contexts in their frameworks in response to the criticisms about neglecting social-cultural factors. However, in most cases, less emphasis is placed on factors related to the general context of society.

For example, Zepke and Leach (2010) identify six themes and their indicators as the main influential factors: student motivation and agency, students-teachers interaction, students - students interactions, university supports (the university culture and providing different facilities for students), out of university supports (family and friends support in the face of time shortage, work and financial problems and family responsibilities), and being an active citizen. In a study, they found that among these factors, the interaction between the teachers and students has the most impact on student engagement.

Zepke (2019) has presented a framework through a critical interpretive synthesis of the recent literature on student engagement. In this framework, he introduced three factors and its promoting catalysts as the influential and essential 
areas in student engagement. Factors are: the students (the extent of motivation, personal characteristics, learning capital and learning approach), the quality of teaching, and the outer environment.

Kahu (2013) and Kahu and Nelson (2018) have also presented a framework consisting of four parts of antecedents, educational interface (dimensions of engagement and mechanisms), consequences, and cultural-social context of student engagement. By adopting a more comprehensive approach and highlighting the role of sociocultural context (social and political environment, culture, economics, power, etc.) they have expanded the domain of effecting factors of student engagement and introduced engagement as a malleable factor influenced by the institution's structural factors (culture, policies, curriculum, disciplines), students (such as background, life loads and responsibilities, family supports), and psychosocial factors of the students and university (such as teaching environment, students workload, student-teacher relationships, motivation, skills, identity, and student's personality) as well. In their next modified framework (Kahu and Nelson, 2018), they considered the educational interface as a psychosocial space for students-university interaction, which influences students' engagement for learning through four mechanisms (self-efficacy, belonging, well-being and emotions).

Considering the complexity, multidimensionality, and malleability of student engagement, despite the abundance of conducted studies, the underlying reasons have not been adequately theorized (Kahn, 2014) and the reasons behind its fluctuations in different time and space conditions require further decoding. In particular, most studies student engagement has emphasized the inner-university and classroom factors and elements (such as student, teachers, and the classroom atmosphere). This is while the drivers and impediments of engagement are not confined to the classroom and institution (Eccles \& Wang, 2012, cited in Lawson \& Lawson, 2013) and it needs to seek them beyond university borders, too. It is true because students' career aspirations and learning interests are influenced by family, peers, community, and society (Lee, 2012; Ream \& Rumberger, 2008; Skinner \& Pitzer, 2012; Tate, 2012; Wylie \& Hodgen, 2012 cited in Lawson \& Lawson, 2013). Besides, most studies have only focused on a few individual and institutional factors. While in the real world, the influential factors constitute a dynamic and non-hierarchical network (Zepke, 2011, cited in Kahu, 2013) which leads to engagement or lack of engagement.

The aim of this paper is primarily to identify impediments of students' engagement in Iran's universities through the application of the Fuzzy Delphi technique. Given the interrelationships among the factors in the real- world, and one cannot analyze and understand each category of impediments in a separate and island-like manner, the interdependencies and causal relationships among the factors are also determined by Fuzzy DEMATEL (decision-making trial and evaluation laboratory) technique. Discovering students' engagement impediments and identifying the factors that have the most impacts, In addition to expanding our awareness and understanding of influencing factors, can open doors to further researches. Additionally, this allows policymakers to adopt appropriate policies to increase student engagement and help practitioners make corrective interventions using available resources efficiently.

\section{Method}

The present study employed two methods of Fuzzy Delphi (Cheng \& Lin, 2002) and Fuzzy DEMATE. Fuzzy Delphi was used to identify the most important impediments to student engagement. Fuzzy DEMATEL was applied to illustrate the interrelationships between criteria and sub-criteria by drawing a causal diagram. Matlab version R2017b and Excel version 2019 were used for data analysis.

\subsection{Fuzzy Delphi Method (FDM)}

First, to compile a list of student engagement impediments, an open questionnaire was administered to 50 graduate students studying at the University of Tehran (a public university) and Islamic Azad University, Science and Research Branch (a private university), and 39 impediments were recorded.

The purpose of the Delphi method is to screen impediments to obtain the most important ones, by using the experts' opinion on successive rounds (Linstone \& Turoff, 2002). The following steps have been taken to accomplish the fuzzy Delphi method:

Step 1: The Delphi questionnaire was distributed among 25 experts selected from various disciplines faculty members with Ph.D. and more than 5 years of teaching experience in graduate courses.

Step 2: They were asked to determine the importance of each impediment using linguistic variables. Linguistic variables and their Corresponding fuzzy Scales (Triangular numbers) for the importance weight of impediment are shown in Table 1. 
Table 1. Linguistic Variables for the Importance of Impediment.

\begin{tabular}{ll}
\hline Linguistic variables & fuzzy Scales \\
\hline Very unimportant & $(0,0,0.1)$ \\
Moderately unimportant & $(0,0.1,0.3)$ \\
unimportant & $(0.1,0.3,0.5)$ \\
Fair & $(0.3,0.5,0.7)$ \\
important & $(0.5,0.7,0.9)$ \\
Moderately important & $(0.7,0.9,1)$ \\
Very unimportant & $(0.9,1,1)$ \\
\hline
\end{tabular}

Step 3: Arithmetic mean were used to aggregate the expert's opinion.

Step 4: According to Cheng \& Lin (2002), the Vertex method was used to calculate the distance between each expert's evaluation and the weight's average. If the distance is less than threshold 0.2 , a consensus has been reached and, the process will end. Otherwise, the second round of Delphi must be performed.

Step 5: If the crisp weight of each impediment was less than the third quarter, then that impediment should be rejected, otherwise it should be Selected (Chu and Hwang, 2008). The Best Non-Performance (BNP) Method was applied for defuzzification.

2.2 Fuzzy DEMATEL

DEMATEL technique is a group multi-criteria decision making which illustrates cause and effect relationship among criteria through a directional graph (Tseng, 2009). The fuzzy DEMATEL technique was applied to determine causal relationships among the main criteria and sub-criteria (impediments to student engagement).

Step 1: After determining critical impediments by fuzzy Delphi method, a questionnaire with two square matrices (a square matrix of order 4 for the main criteria and, a square matrix of order 23 for sub-criteria) was prepared to a pairwise comparison of the impediments.

Step 2: A 30-expert panel was invited to evaluate interrelations among the impediments by pairwise comparisons.

Step 3: The experts used ten linguistic variables to illustrate the degree of causality between the impediments. Linguistic variables and their corresponding triangular fuzzy numbers to define the degree of influence of impediments are shown in Table 2 .

Table 2. Linguistic Variables for the Degree of Influence of the Impediment.

\begin{tabular}{ll}
\hline Linguistic variables & fuzzy Scales \\
\hline No influence (N) & $(0,0,0)$ \\
Extremely low influence (EL) & $(0,0,0.1)$ \\
Very low influence (VL) & $(0,0.1,0.2)$ \\
Moderately low influence (ML) & $(0.1,0.2,0.3)$ \\
Low influence (L) & $(0.2,0.3,0.4)$ \\
Medium influence (M) & $(0.3,0.4,0.5)$ \\
High influence (H) & $(0.4,0.5,0.6)$ \\
Moderately high influence (MH) & $(0.5,0.6,0.7)$ \\
Very high influence (VL) & $(0.6,0.7,0.8)$ \\
Extremely high influence (EL) & $(0.7,0.8,0.9)$ \\
\hline
\end{tabular}

After converting linguistic variables to triangular fuzzy numbers based on table 2 , the Initial direct-relation matrix for the $\mathrm{k}_{\mathrm{th}}$ expert was made as $\tilde{X}^{k}=\left[\tilde{X}_{i j}^{k}\right]_{n \times n} k=1,2, \cdots, m ; m=30$ and, $\mathrm{n}$ is the number of impediment where $i, j=1,2, \cdots, n$. Each element in matrix $\tilde{X}^{k} i . e . \widetilde{X}_{i j}^{k}=\left(l_{i j}^{k}, m_{i j}^{k}, u_{i j}^{k}\right)$ is a triangular fuzzy number that denotes the degree of the ith impediment affects the jth impediment when $i \neq j$ and, is equal to $(0,0,0)$ when $i=j$.

Step 4: using the combination rule of fuzzy triangular numbers, i.e. equation 1 aggregated direct-relation matrix $\tilde{A}=$ $\left[\tilde{a}_{i j}\right]_{n \times n}(i, j=1,2, \cdots, n)$ was achieved.

$$
\tilde{a}_{i j}=\frac{1}{m}\left[x_{i j}^{1}(+) x_{i j}^{2}(+) \cdots(+) x_{i j}^{m}\right]
$$


Where $(+)$ denotes Chen's fuzzy addition operation of triangular fuzzy numbers.

Step 5: Let $\tilde{G}=\left[\tilde{g}_{i j}\right]_{n \times n}(i, j=1,2, \cdots, n)$ be the normalized direct-relation matrix that was calculated by applying equations 2 to 4 .

Assume that each element in aggregated direct-relation matrix $\tilde{A}$ is $\tilde{a}_{i j}=\left(l_{i j}^{\prime}, m_{i j}^{\prime}, u_{i j}^{\prime}\right)(i, j=1,2, \cdots, n)$.

$$
\begin{aligned}
& {\left[\tilde{c}_{i}\right]_{n \times 1}=\left(\sum_{j=1}^{n} l_{i j}^{\prime}, \sum_{j=1}^{n} m_{i j}^{\prime}, \sum_{j=1}^{n} u_{i j}^{\prime}\right) i=1,2, \cdots, n} \\
& c=\max _{1 \leq i \leq n}\left(\sum_{j=1}^{n} u_{i j}^{\prime}\right) \\
& \tilde{G}=\left[\tilde{g}_{i j}\right]_{n \times n}=\left(\frac{\sum_{j=1}^{n} l_{i j}^{\prime}}{c}, \frac{\sum_{j=1}^{n} m_{i j}^{\prime}}{c}, \frac{\sum_{j=1}^{n} u_{i j}^{\prime}}{c}\right) i, j=1,2, \cdots, n
\end{aligned}
$$

Step 6: The total direct-relation matrix $\tilde{S}=\left[\tilde{s}_{i j}\right]_{n \times n}^{c}(i, j=1,2, \cdots, n)$ where $\tilde{s}_{i j}=\left(l_{i j}^{\prime \prime}, m_{i j}^{\prime \prime}, u_{i j}^{\prime \prime}\right)$ was calculated as follows:

By dividing $\tilde{G}$ and $\tilde{S}$ to three crisp matrices of their lower, middle and upper elements of fuzzy triangular number, $\tilde{S}$ can be obtained by using equations 5 to 7 .

$$
\begin{aligned}
& {\left[l_{i j}^{\prime \prime}\right]_{n \times n}=\left[l_{i j}^{\prime}\right]_{n \times n} \times\left([I]_{n \times n}-\left[l_{i j}^{\prime}\right]_{n \times n}\right)^{-1}} \\
& {\left[m_{i j}^{\prime \prime}\right]_{n \times n}=\left[m_{i j}^{\prime}\right]_{n \times n} \times\left([I]_{n \times n}-\left[m_{i j}^{\prime}\right]_{n \times n}\right)^{-1}} \\
& {\left[u_{i j}^{\prime \prime}\right]_{n \times n}=\left[u_{i j}^{\prime}\right]_{n \times n} \times\left([I]_{n \times n}-\left[u_{i j}^{\prime}\right]_{n \times n}\right)^{1}}
\end{aligned}
$$

Where $\mathrm{I}$ is the identity matrix of order $\mathrm{n}$.

Step 7: The sum of each row and column of the total direct-relation matrix was stamped as two vectors $\widetilde{D}=\left[\tilde{d}_{i}\right]_{n \times 1}$, $(i=1,2, \cdots, n)$ and, $\tilde{R}=\left[\tilde{r}_{n}\right]_{n \times 1}(j=1,2, \cdots, n)$ respectively. By adding $\widetilde{D}$ to $\widetilde{R}(\widetilde{D}+\tilde{R})$ "prominence" was made which indicates the importance of each criterion. Subtracting $\widetilde{D}$ from $\widetilde{R}(\widetilde{D}-\widetilde{R})$ "relation" was obtained. Then, $=\left[d_{i}\right]_{n \times 1}, R=\left[r_{J}\right]_{1 \times n}, \vec{D}+\vec{R}$ and, $\vec{D}-\vec{R}$ vectors were defuzzified by Best Non-Performance (BNP) method. When $i=j$, if $d_{i}>r_{j} \rightarrow d_{i}-r_{j}>0$, then the criterion is a net cause; When $i=j$, if $d_{i}<r_{j} \rightarrow d_{i}-$ $r_{j}<0$, then criterion is a net effect. $d_{i}$ indicates the sum of direct and indirect effects of criterion $i$ on other criteria. $r_{j}$ indicates the sum of direct and indirect effects of criterion $\mathrm{j}$.

Step 8: A Cartesian coordinate system consisted of a horizontal axis $(\vec{D}+\vec{R})$ and a vertical axis $(\vec{D}-\vec{R})$ was drawn in which the coordinates of each criterion are displayed in ordered pairs $\left(d_{i}+r_{j}, d_{i}-r_{j}\right)$.

Step 9: The impact relationship map for the criteria was drawn based on the defuzzified total direct-relation matrix. To demonstrate the most influential and influenced impediments a threshold value considered for main criteria and sub-criteria. The sequence of various steps of 3 phases is shown in Figure 1. 


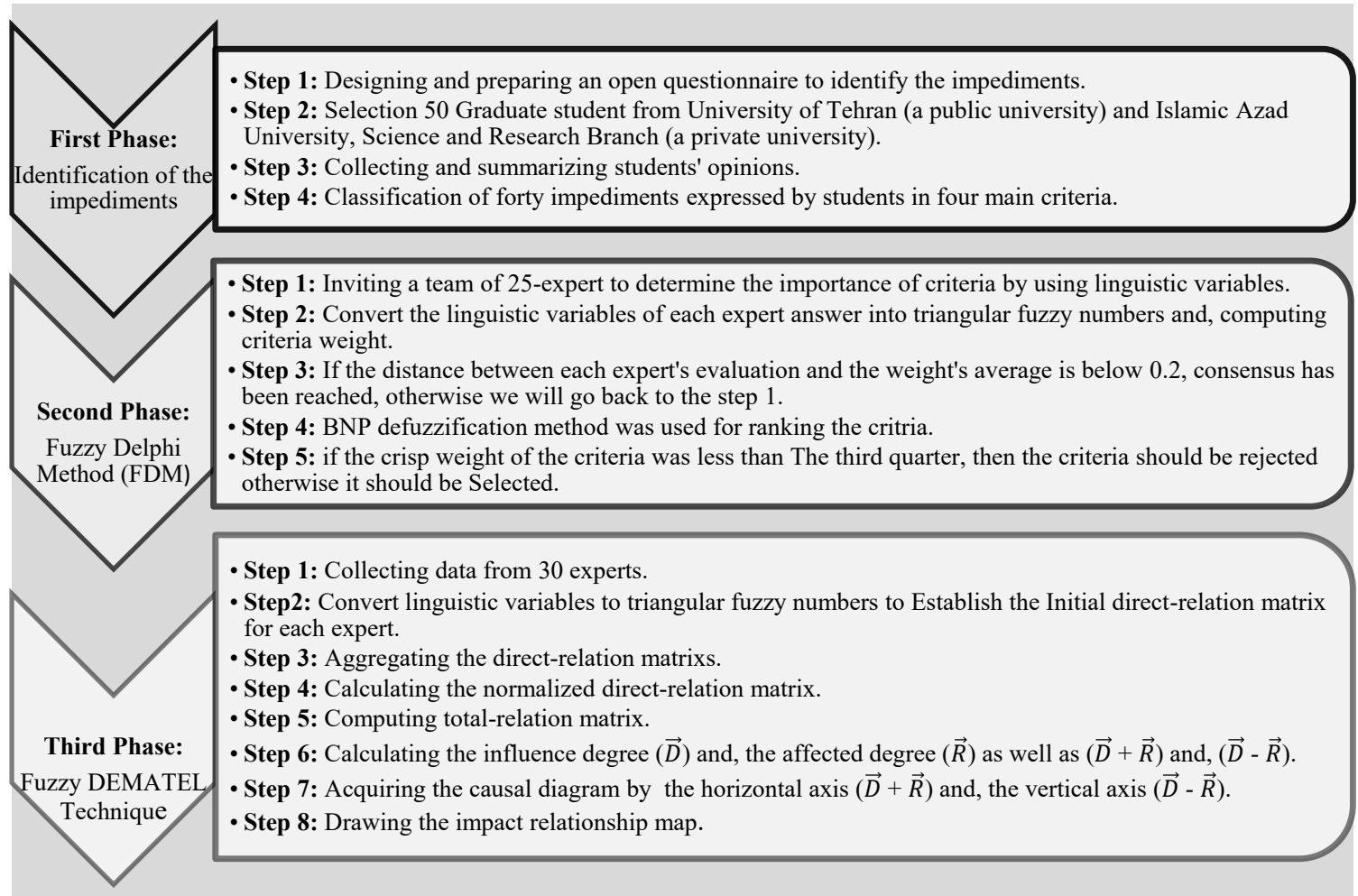

Figure 1. The Study Stages and Steps

\section{Results}

\subsection{Selection of Important Impediments to Student Engagement}

Important impediments were identified by experts through the fuzzy Delphi. During the two rounds, the experts reached a consensus. As table 3 shows, of the 39 impediments identified through the open-ended questionnaire, experts selected 23 impediments as significant impediments and rejected 16 impediments.

Table 3. Fuzzy Delphi Method (FDM) Results

\begin{tabular}{|c|c|c|c|c|c|}
\hline $\begin{array}{c}\text { Main } \\
\text { impediment }\end{array}$ & Sub- impediment & $\begin{array}{c}\text { The } 1^{\text {st }} \text { round fuzzy } \\
\text { weight }\end{array}$ & $\begin{array}{c}\text { The } 2^{\text {st }} \text { round fuzzy } \\
\text { Weight }\end{array}$ & $\begin{array}{l}\text { The } 2^{\text {st }} \text { round } \\
\text { crisp weight }\end{array}$ & Result \\
\hline \multirow{6}{*}{$\begin{array}{l}\text { Environmental } \\
\text { factors }\end{array}$} & - Alumni unemployment & $(0.716,0.88,0.712)$ & $(0.788,0.944,0.944)$ & 0.892 & Selected \\
\hline & - Credentialism in society & $(0.66,0.832,0.544)$ & $(0.796,0.948,0.948)$ & 0.897 & Selected \\
\hline & $\begin{array}{l}\text { - The lack of relationship } \\
\text { between education and income }\end{array}$ & $(0.668,0.848,0.632)$ & $(0.804,0.952,0.952)$ & 0.903 & Selected \\
\hline & $\begin{array}{l}\text { - Decreasing the value and } \\
\text { status of education in the society }\end{array}$ & $(0.724,0.888,0.744)$ & $(0.788,0.944,0.944)$ & 0.892 & Selected \\
\hline & $\begin{array}{l}\text { - Low impact of education on } \\
\text { social mobility }\end{array}$ & $(0.732,0.888,0.72)$ & $(0.804,0.952,0.952)$ & 0.903 & Rejected \\
\hline & $\begin{array}{l}\text { - Lack of job security for the } \\
\text { educated people }\end{array}$ & $(0.436,0.636,0.684)$ & $(0.396,0.596,0.516)$ & 0.503 & Rejected \\
\hline \multirow{4}{*}{$\begin{array}{c}\text { University } \\
\text { (institutional) } \\
\text { factors }\end{array}$} & $\begin{array}{l}\text { - Inappropriate student } \\
\text { evaluation methods }\end{array}$ & $(0.412,0.612,0.652)$ & $(0.38,0.58,0.58)$ & 0.513 & Selected \\
\hline & - Inappropriate timing of classes & $(0.74,0.904,0.808)$ & $(0.788,0.944,0.944)$ & 0.892 & Selected \\
\hline & $\begin{array}{l}\text { - Strict administrative and } \\
\text { educational regulations }\end{array}$ & $(0.74,0.904,0.808)$ & $(0.796,0.948,0.948)$ & 0.897 & Selected \\
\hline & $\begin{array}{l}\text { - Inappropriate staff behavior } \\
\text { with students }\end{array}$ & $(0.452,0.652,0.612)$ & $(0.404,0.604,0.484)$ & 0.497 & Rejected \\
\hline
\end{tabular}




\begin{tabular}{|c|c|c|c|c|c|}
\hline & $\begin{array}{l}\text { - Non applicable material and } \\
\text { curriculum }\end{array}$ & $(0.668,0.844,0.604)$ & $(0.788,0.944,0.944)$ & 0.892 & Selected \\
\hline & - Teachers' unclear expectations & $(0.412,0.612,0.612)$ & $(0.38,0.58,0.58)$ & 0.513 & Rejected \\
\hline & $\begin{array}{l}\text { - Teachers' poor quality of } \\
\text { teaching }\end{array}$ & $(0.7,0.864,0.648)$ & $(0.788,0.944,0.944)$ & 0.892 & Selected \\
\hline & $\begin{array}{l}\text { - Lack of student involvement in } \\
\text { decision-making }\end{array}$ & $(0.436,0.636,0.684)$ & $(0.452,0.652,0.292)$ & 0.465 & Rejected \\
\hline & - Strict climate of classrooms & $(0.388,0.588,0.644)$ & $(0.356,0.556,0.676)$ & 0.529 & Rejected \\
\hline & $\begin{array}{l}\text { - Poor quality of relationship } \\
\text { between Teachers and students }\end{array}$ & $(0.692,0.868,0.7)$ & $(0.788,0.944,0.944)$ & 0.892 & Selected \\
\hline & $\begin{array}{l}\text { - Perceived injustice in the } \\
\text { classroom }\end{array}$ & $(0.396,0.596,0.692)$ & $(0.452,0.652,0.292)$ & 0.465 & Rejected \\
\hline & $\begin{array}{l}\text { - Lack of students participation } \\
\text { in class activities }\end{array}$ & $(0.388,0.588,0.62)$ & $(0.356,0.556,0.676)$ & 0.529 & Rejected \\
\hline & $\begin{array}{l}\text { - Inadequate facilities of } \\
\text { classroom and institution }\end{array}$ & $(0.676,0.856,0.664)$ & $(0.812,0.956,0.956)$ & 0.908 & Selected \\
\hline & $\begin{array}{l}\text { - Distance from home to } \\
\text { university }\end{array}$ & $(0.388,0.588,0.684)$ & $(0.428,0.628,0.388)$ & 0.481 & Rejected \\
\hline Personal factors & $\begin{array}{l}\text { - Financial problems and High } \\
\text { tuition fees }\end{array}$ & $(0.74,0.908,0.836)$ & $(0.788,0.944,0.944)$ & 0.892 & Selected \\
\hline & - Lack of hope for future & $(0.42,0.62,0.572)$ & $(0.444,0.644,0.324)$ & 0.471 & Rejected \\
\hline & - Job insecurity in the future & $(0.772,0.912,0.768)$ & $(0.796,0.948,0.948)$ & 0.897 & Selected \\
\hline & - Being busy and lack of time & $(0.772,0.92,0.824)$ & $(0.78,0.94,0.94)$ & 0.887 & Selected \\
\hline & - Lack of self-efficacy & $(0.724,0.892,0.772)$ & $(0.788,0.944,0.944)$ & 0.892 & Selected \\
\hline & $\begin{array}{l}\text { - Lack of interest in the field of } \\
\text { study }\end{array}$ & $(0.7,0.872,0.704)$ & $(0.788,0.944,0.944)$ & 0.892 & Selected \\
\hline & - Low motivation & $(0.412,0.612,0.612)$ & $(0.388,0.588,0.548)$ & 0.508 & Rejected \\
\hline & - Exam stress & $(0.42,0.62,0.732)$ & $(0.364,0.564,0.644)$ & 0.524 & Rejected \\
\hline & - Poor study skills & $(0.396,0.596,0.764)$ & $(0.444,0.644,0.324)$ & 0.471 & Rejected \\
\hline & $\begin{array}{l}\text { - Lack of strong academic } \\
\text { background }\end{array}$ & $(0.396,0.596,0.508)$ & $(0.372,0.572,0.612)$ & 0.519 & Rejected \\
\hline & - Mental and physical illnesses & $(0.724,0.896,0.8)$ & $(0.788,0.944,0.944)$ & 0.892 & Selected \\
\hline & - Life dissatisfaction & $(0.396,0.596,0.548)$ & $(0.348,0.548,0.708)$ & 0.535 & Rejected \\
\hline Family factors & $\begin{array}{l}\text { - Marriage and responsibility } \\
\text { for child care }\end{array}$ & $(0.74,0.912,0.864)$ & $(0.788,0.944,0.944)$ & 0.892 & Selected \\
\hline & - Family problems and conflicts & $(0.636,0.82,0.532)$ & $(0.788,0.944,0.944)$ & 0.892 & Selected \\
\hline & - Lack of supports by the family & $(0.684,0.856,0.64)$ & $(0.788,0.944,0.944)$ & 0.892 & Selected \\
\hline & $\begin{array}{l}\text { - Family problems and } \\
\text { preoccupations }\end{array}$ & $(0.412,0.612,0.548)$ & $(0.428,0.628,0.388)$ & 0.481 & Rejected \\
\hline & $\begin{array}{l}\text { - Lack of financial supports by } \\
\text { the family }\end{array}$ & $(0.7,0.88,0.76)$ & $(0.788,0.944,0.944)$ & 0.892 & Selected \\
\hline & $\begin{array}{l}\text { - Family's unreasonable } \\
\text { expectations }\end{array}$ & $(0.756,0.912,0.816)$ & $(0.796,0.948,0.948)$ & 0.897 & Selected \\
\hline & - Being far from the family & $(0.732,0.908,0.86)$ & $(0.788,0.944,0.944)$ & 0.892 & Selected \\
\hline
\end{tabular}

\subsection{Fuzzy DEMATEL Calculations}

By gathering expert opinion using the pairwise comparisons matrix for the main impediments and, sub-impediments, the linguistic variables were converted to triangular fuzzy numbers. The experts' opinions were combined by using Equation (1). Then, the normalized direct-relation matrix, fuzzy, and crisp total direct-relation matrix were calculated. The fuzzy and, crisp total direct-relation matrix for main impediments is illustrated in tables 4,5 respectively. 
Table 4. The Fuzzy Total Direct-relation Matrix $(\tilde{S})$ for the Main Impediments

\begin{tabular}{cccccc}
\hline Abb. & & $\mathrm{C} 01$ & $\mathrm{C} 02$ & $\mathrm{C} 03$ & $\mathrm{C} 04$ \\
\hline & Main impediments & $\begin{array}{c}\text { Environmental } \\
\text { factors }\end{array}$ & University factors & Personal factors & Family factors \\
& & & & & \\
$\mathrm{C} 01$ & Environmental factors & $(0.11,0.32,1.08)$ & $(0.27,0.52,1.32)$ & $(0.42,0.75,1.79)$ & $(0.21,0.48,1.32)$ \\
$\mathrm{C} 02$ & University factors & $(0.31,0.56,1.36)$ & $(0.1,0.31,1.07)$ & $(0.37,0.7,1.75)$ & $(0.24,0.5,1.34)$ \\
$\mathrm{C} 03$ & Personal factors & $(0.14,0.34,0.99)$ & $(0.14,0.34,0.98)$ & $(0.1,0.32,1.11)$ & $(0.16,0.37,1.04)$ \\
$\mathrm{C} 04$ & Family factors & $(0.1,0.29,0.88)$ & $(0.08,0.28,0.88)$ & $(0.28,0.52,1.3)$ & $(0.05,0.21,0.78)$ \\
\hline
\end{tabular}

Table 5. The Crisp Total Direct-relation Matrix (S) for the Main Impediments

\begin{tabular}{llllll}
\hline Abb. & & C01 & C02 & C03 & C04 \\
\hline & Main impediments & Environmental factors & University factors & Personal factors & Family factors \\
C01 & Environmental factors & 0.506 & 0.702 & 0.987 & 0.674 \\
C02 & University factors & 0.741 & 0.495 & 0.941 & 0.693 \\
C03 & Personal factors & 0.489 & 0.486 & 0.513 & 0.524 \\
C04 & Family factors & 0.426 & 0.412 & 0.700 & 0.348 \\
\hline
\end{tabular}

A threshold of 0.602 obtained from the average of all elements of the total relation matrix, is considered to indicate the strongest interdependence among criteria.

As the table shows, environmental factors affect all three other factors (institutional, family, and personal) but are only influenced by University factors. University factors influence all three other factors (environmental, family, and personal), and are affected by environmental factors. Family factors only affect personal factors. Personal factors are affected by all three other factors (environmental, institutional, and family), but doesn't affect any of them.

Table 6. The Sum of Rows $(\widetilde{D})$ and the Sum of Columns $(\widetilde{R})$ for Fuzzy Total-relation Matrix and Their Corresponding Crisp Values for Main Impediments

\begin{tabular}{llllll}
\hline Abb. & Main impediments & $\widetilde{D}$ in triangular fuzzy form & $\tilde{R}$ in triangular fuzzy form & $\begin{array}{l}\vec{D} \text { in crisp } \\
\text { form }\end{array}$ & $\begin{array}{l}\vec{R} \text { in crisp } \\
\text { form }\end{array}$ \\
\hline C01 & Environmental factors & $(1.015,2.075,5.519)$ & $(0.659,1.518,2.176)$ & 2.870 & 1.451 \\
C02 & University factors & $(1.018,2.076,5.516)$ & $(0.586,1.449,2.035)$ & 2.870 & 1.357 \\
C03 & Personal factors & $(0.537,1.382,4.119)$ & $(1.171,2.297,3.467)$ & 2.013 & 2.312 \\
C04 & Family factors & $(0.51,1.296,3.852)$ & $(0.664,1.565,2.23)$ & 1.886 & 1.486 \\
\hline
\end{tabular}

Table 7. The "Prominence" and "Relation" Values in the Form of Triangular Fuzzy and Crisp Numbers for Main Impediments

\begin{tabular}{|c|c|c|c|c|c|c|}
\hline Abb. & Main impediments & $\tilde{\mathrm{D}^{2}+\mathrm{R}^{\tilde{n}}}$ & $\tilde{D^{2}-R^{\sim}}$ & $\left(D^{\rightarrow}+R^{\rightarrow}\right)$ & $\left(D^{\rightarrow}-R^{\rightarrow}\right)$ & Category \\
\hline $\mathrm{C} 01$ & Environmental factors & $(1.674,3.593,7.695)$ & $(0.357,0.558,3.342)$ & 4.321 & 1.419 & net cause \\
\hline $\mathrm{C} 02$ & University factors & $(1.604,3.525,7.552)$ & $(0.432,0.627,3.481)$ & 4.227 & 1.513 & net cause \\
\hline $\mathrm{C} 03$ & Personal factors & $(1.708,3.679,7.586)$ & $(-0.633,-0.915,0.651)$ & 4.324 & -0.299 & Net effect \\
\hline $\mathrm{C} 04$ & Family factors & $(1.174,2.861,6.082)$ & $(-0.155,-0.27,1.623)$ & 3.372 & 0.399 & net cause \\
\hline $\mathrm{C} 01$ & Environmental factors & $(1.674,3.593,7.695)$ & $(0.357,0.558,3.342)$ & 4.321 & 1.419 & net cause \\
\hline
\end{tabular}

Criterion (C03) Personal factors has the most interaction with other criteria and since $\left(D_{i}-R_{i}\right)$ is negative for Personal factors, so this criterion is a net effect.

Criterion (C01) Environmental factors after Personal factors has the most interaction with other criteria and since $\left(D_{i}-\right.$ $\left.R_{i}\right)$ is positive for Environmental factors, so this criterion is a net cause. Given that the value $\left(D_{i}-R_{i}\right)$ is positive, the criteria of University factors and Family factors are also net cause. 


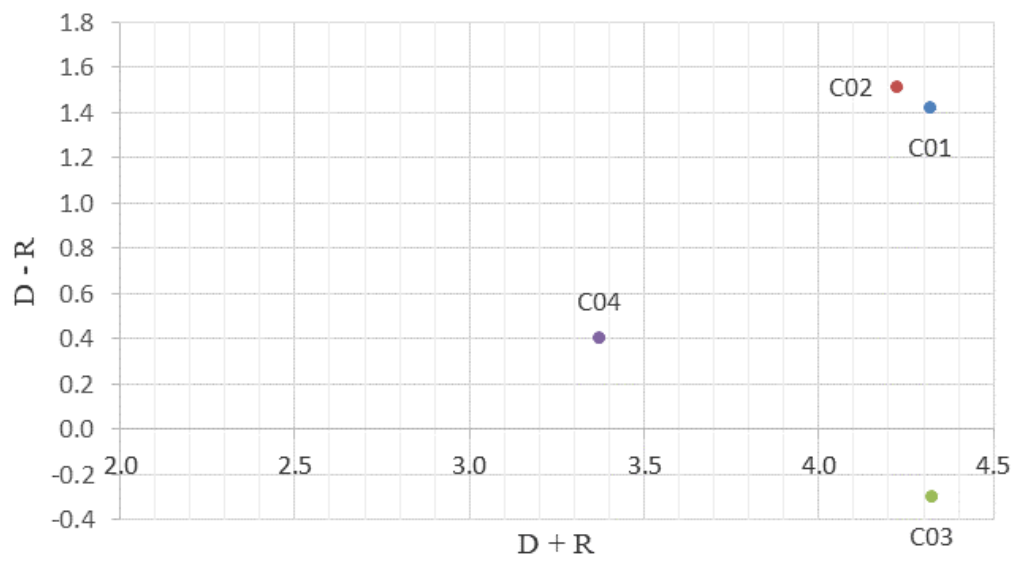

Diagram 1. The Causal Diagram from the Crisp Data for Main Impediments

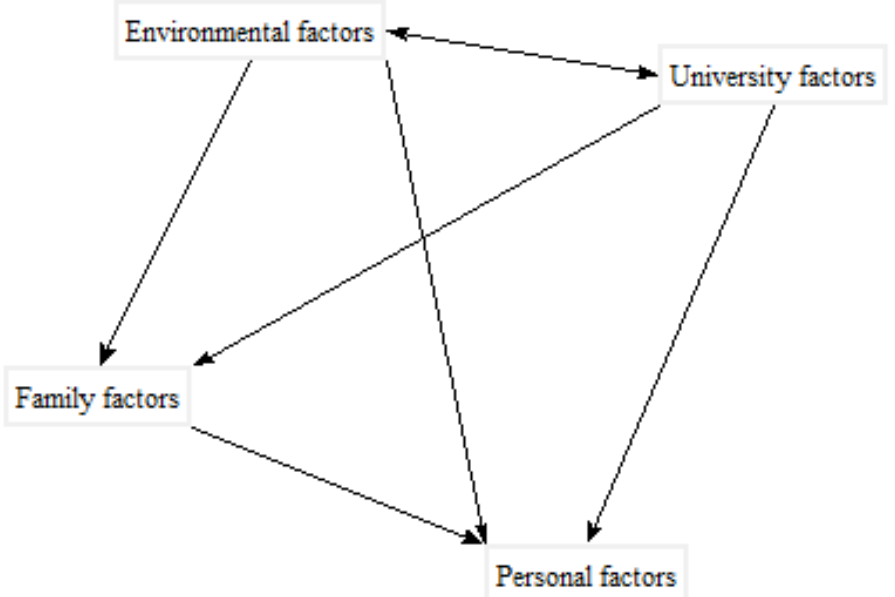

Diagram 2. The Impact Relationship Map (IRM) for the Main Impediments

Table 8. The Sum of Rows $(\widetilde{D})$ and the Sum of Columns $(\widetilde{R})$ for Fuzzy Total-relation Matrix and Their Corresponding Crisp Values for Sub-impediments

\begin{tabular}{|c|c|c|c|c|c|}
\hline Abb. & Sub-impediments & $\begin{array}{c}\widetilde{D} \text { in triangular fuzzy } \\
\text { number form }\end{array}$ & $\begin{array}{c}\tilde{R} \text { in triangular fuzzy } \\
\text { number form }\end{array}$ & $\begin{array}{l}\vec{D} \text { in crisp } \\
\text { form }\end{array}$ & $\begin{array}{l}\vec{R} \text { in crisp } \\
\text { form }\end{array}$ \\
\hline $\mathrm{C} 011$ & alumni unemployment & $(1.011,1.678,2.901)$ & $(1.004,1.645,2.811)$ & 1.863 & 1.820 \\
\hline $\mathrm{C} 012$ & Credentialism in society & $(1.045,1.755,3.055)$ & $(0.546,0.965,1.733)$ & 1.952 & 1.081 \\
\hline $\mathrm{C} 013$ & $\begin{array}{l}\text { The lack of relationship between } \\
\text { education and income }\end{array}$ & $(0.442,0.829,1.551)$ & $(0.359,0.717,1.36)$ & 0.940 & 0.812 \\
\hline $\mathrm{C} 014$ & $\begin{array}{l}\text { Decreasing the value and status of } \\
\text { education in the society }\end{array}$ & $(0.739,1.298,2.336)$ & $(0.918,1.462,2.449)$ & 1.458 & 1.610 \\
\hline $\mathrm{C} 015$ & $\begin{array}{l}\text { low impact of education on social } \\
\text { mobility }\end{array}$ & $(0.524,0.996,1.869)$ & $(0.668,1.151,2.033)$ & 1.130 & 1.284 \\
\hline $\mathrm{C} 021$ & Inappropriate timing of classes & $(0.363,0.69,1.295)$ & $(0.305,0.497,0.838)$ & 0.782 & 0.547 \\
\hline $\mathrm{C} 022$ & $\begin{array}{l}\text { Strict administrative and educational } \\
\text { regulations }\end{array}$ & $(0.316,0.732,1.505)$ & $(0.153,0.273,0.487)$ & 0.851 & 0.304 \\
\hline $\mathrm{C} 023$ & $\begin{array}{l}\text { Non applicable material and } \\
\text { curriculum }\end{array}$ & $(0.909,1.513,2.645)$ & $(0.418,0.642,1.035)$ & 1.689 & 0.698 \\
\hline $\mathrm{C} 024$ & Teachers' poor quality of teaching & $(1.032,1.693,2.934)$ & $(0.426,0.723,1.252)$ & 1.886 & 0.800 \\
\hline
\end{tabular}




\begin{tabular}{|c|c|c|c|c|c|}
\hline $\mathrm{C} 025$ & $\begin{array}{l}\text { Poor quality of relationship between } \\
\text { Teachers and students }\end{array}$ & $(0.77,1.361,2.461)$ & $(0.796,1.376,2.439)$ & 1.531 & 1.537 \\
\hline $\mathrm{C} 026$ & $\begin{array}{l}\text { inadequate facilities of classroom and } \\
\text { institution }\end{array}$ & $(0.675,1.235,2.281)$ & $(0.209,0.348,0.602)$ & 1.397 & 0.387 \\
\hline $\mathrm{C} 031$ & $\begin{array}{l}\text { Financial problems and high tuition } \\
\text { fees }\end{array}$ & $(0.375,0.712,1.322)$ & $(0.371,0.75,1.462)$ & 0.803 & 0.861 \\
\hline $\mathrm{C} 032$ & Job insecurity in the future & $(0.917,1.548,2.706)$ & $(1.019,1.702,2.96)$ & 1.724 & 1.894 \\
\hline $\mathrm{C} 033$ & Being busy and lack of time & $(0.723,1.288,2.312)$ & $(0.803,1.43,2.599)$ & 1.441 & 1.611 \\
\hline $\mathrm{C} 034$ & Lack of self-efficacy & $(0.469,0.941,1.808)$ & $(1.003,1.784,3.226)$ & 1.073 & 2.004 \\
\hline $\mathrm{C} 035$ & Lack of interest in the field of study & $(0.615,1.159,2.172)$ & $(1.205,2.014,3.493)$ & 1.315 & 2.237 \\
\hline $\mathrm{C} 036$ & Mental and physical illnesses & $(0.816,1.368,2.383)$ & $(1.258,2.19,3.905)$ & 1.522 & 2.451 \\
\hline $\mathrm{C} 041$ & $\begin{array}{l}\text { Marriage and responsibility for child } \\
\text { care }\end{array}$ & $(0.47,0.783,1.348)$ & $(0.576,1.101,2.083)$ & 0.867 & 1.254 \\
\hline $\mathrm{C} 042$ & Family problems and conflicts & $(0.579,0.982,1.711)$ & $(1.131,1.945,3.46)$ & 1.091 & 2.178 \\
\hline C043 & Lack of supports by the family & $(0.575,0.928,1.567)$ & $(0.59,1.148,2.188)$ & 1.023 & 1.309 \\
\hline C044 & $\begin{array}{l}\text { Lack of financial supports by the } \\
\text { family }\end{array}$ & $(0.511,0.879,1.546)$ & $(0.385,0.811,1.615)$ & 0.979 & 0.937 \\
\hline C045 & Family's unreasonable expectations & $(0.459,0.786,1.374)$ & $(0.333,0.675,1.324)$ & 0.873 & 0.777 \\
\hline $\mathrm{C} 046$ & Being far from the family & $(0.237,0.398,0.684)$ & $(0.092,0.202,0.414)$ & 0.439 & 0.236 \\
\hline
\end{tabular}

Among the sub-criteria, Credentialism in society and Teachers' poor quality of teaching had the most impact and being far from the family had the least impact.

Among the sub-criteria, Mental and physical illnesses and Lack of interest in the field of study had the highest impact and Being far from the family had the lowest impact, respectively.

Table 9. The "Prominence" and "Relation" Values in the Form of Triangular Fuzzy and Crisp Numbers for Sub-impediments

\begin{tabular}{|c|c|c|c|c|c|c|}
\hline Abb. & $\widetilde{D}+\tilde{R}$ & $\widetilde{D}-\tilde{R}$ & $(\vec{D}+\vec{R})$ & $(\vec{D}-\vec{R})$ & status & $(\vec{D}+\vec{R}) /(\vec{D}-\vec{R})$ \\
\hline $\mathrm{C} 011$ & $(2.015,3.323,5.712)$ & $(0.007,0.033,0.09)$ & 3.683 & 0.043 & net cause & \\
\hline C012 & $(1.591,2.72,4.788)$ & $(0.5,0.789,1.323)$ & 3.033 & 0.871 & net cause & \\
\hline $\mathrm{C} 013$ & $(0.801,1.546,2.911)$ & $(0.083,0.112,0.19)$ & 1.752 & 0.129 & net cause & \\
\hline C014 & $(1.657,2.76,4.785)$ & $(-0.179,-0.164,-0.114)$ & 3.067 & -0.152 & net effect & \\
\hline $\mathrm{C} 015$ & $(1.192,2.147,3.903)$ & $(-0.145,-0.155,-0.164)$ & 2.414 & -0.154 & net effect & \\
\hline $\mathrm{C} 021$ & $(0.668,1.187,2.133)$ & $(0.058,0.193,0.457)$ & 1.329 & 0.236 & net cause & \\
\hline $\mathrm{C} 022$ & $(0.469,1.005,1.993)$ & $(0.164,0.459,1.018)$ & 1.156 & 0.547 & net cause & \\
\hline $\mathrm{C} 023$ & $(1.326,2.154,3.68)$ & $(0.491,0.871,1.611)$ & 2.387 & 0.991 & net cause & \\
\hline C024 & $(1.458,2.417,4.186)$ & $(0.606,0.97,1.682)$ & 2.687 & 1.086 & net cause & \\
\hline $\mathrm{C} 025$ & $(1.566,2.737,4.9)$ & $(-0.026,-0.014,0.023)$ & 3.068 & -0.006 & net effect & \\
\hline C026 & $(0.884,1.583,2.884)$ & $(0.466,0.886,1.679)$ & 1.784 & 1.010 & net cause & \\
\hline $\mathrm{C} 031$ & $(0.747,1.462,2.784)$ & $(0.004,-0.038,-0.14)$ & 1.664 & -0.058 & net effect & \\
\hline $\mathrm{C} 032$ & $(1.937,3.25,5.666)$ & $(-0.102,-0.154,-0.254)$ & 3.617 & -0.170 & net effect & \\
\hline $\mathrm{C} 033$ & $(1.526,2.718,4.91)$ & $(-0.081,-0.142,-0.287)$ & 3.051 & -0.170 & net effect & \\
\hline $\mathrm{C} 034$ & $(1.472,2.725,5.034)$ & $(-0.534,-0.843,-1.418)$ & 3.077 & -0.932 & net effect & \\
\hline $\mathrm{C} 035$ & $(1.82,3.173,5.665)$ & $(-0.591,-0.855,-1.321)$ & 3.553 & -0.922 & net effect & \\
\hline $\mathrm{C} 036$ & $(2.075,3.558,6.288)$ & $(-0.442,-0.822,-1.522)$ & 3.974 & -0.929 & net effect & \\
\hline C041 & $(1.047,1.884,3.431)$ & $(-0.106,-0.319,-0.734)$ & 2.121 & -0.386 & net effect & \\
\hline C042 & $(1.71,2.927,5.17)$ & $(-0.552,-0.963,-1.749)$ & 3.269 & -1.088 & net effect & \\
\hline $\mathrm{C} 043$ & $(1.165,2.076,3.755)$ & $(-0.016,-0.22,-0.621)$ & 2.332 & -0.285 & net effect & \\
\hline C044 & $(0.896,1.69,3.161)$ & $(0.126,0.068,-0.069)$ & 1.915 & 0.042 & net cause & \\
\hline C045 & $(0.792,1.46,2.698)$ & $(0.126,0.111,0.05)$ & 1.650 & 0.096 & net cause & \\
\hline $\mathrm{C} 046$ & $(0.329,0.6,1.098)$ & $(0.145,0.196,0.27)$ & 0.675 & 0.204 & net cause & \\
\hline
\end{tabular}

Sub-criterion (C036) Mental and physical illnesses has the most interaction with other sub-criteria and since $\left(D_{i}-R_{i}\right)$ is negative for Mental and physical illnesses, so this sub-criterion is a net effect. 
Given that the value $\left(D_{i}-R_{i}\right)$ for the sub-criterion (C024) Teachers' poor quality of teaching is positive and the highest value, so this sub-criterion is a net cause with the highest net effect.

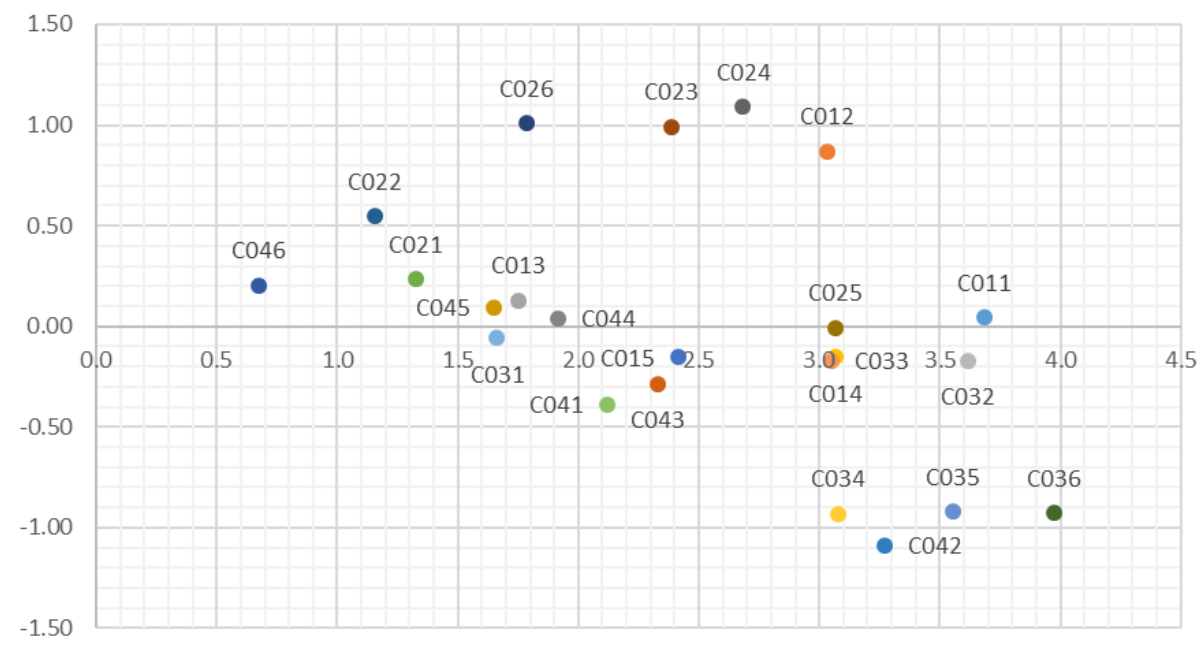

Diagram 3. The Causal Diagram from the Crisp Data for Sub Impediments

A threshold of 0.054 obtained from the average of all elements of the total relation matrix, is considered to indicate the strongest interdependence among sub-criteria.

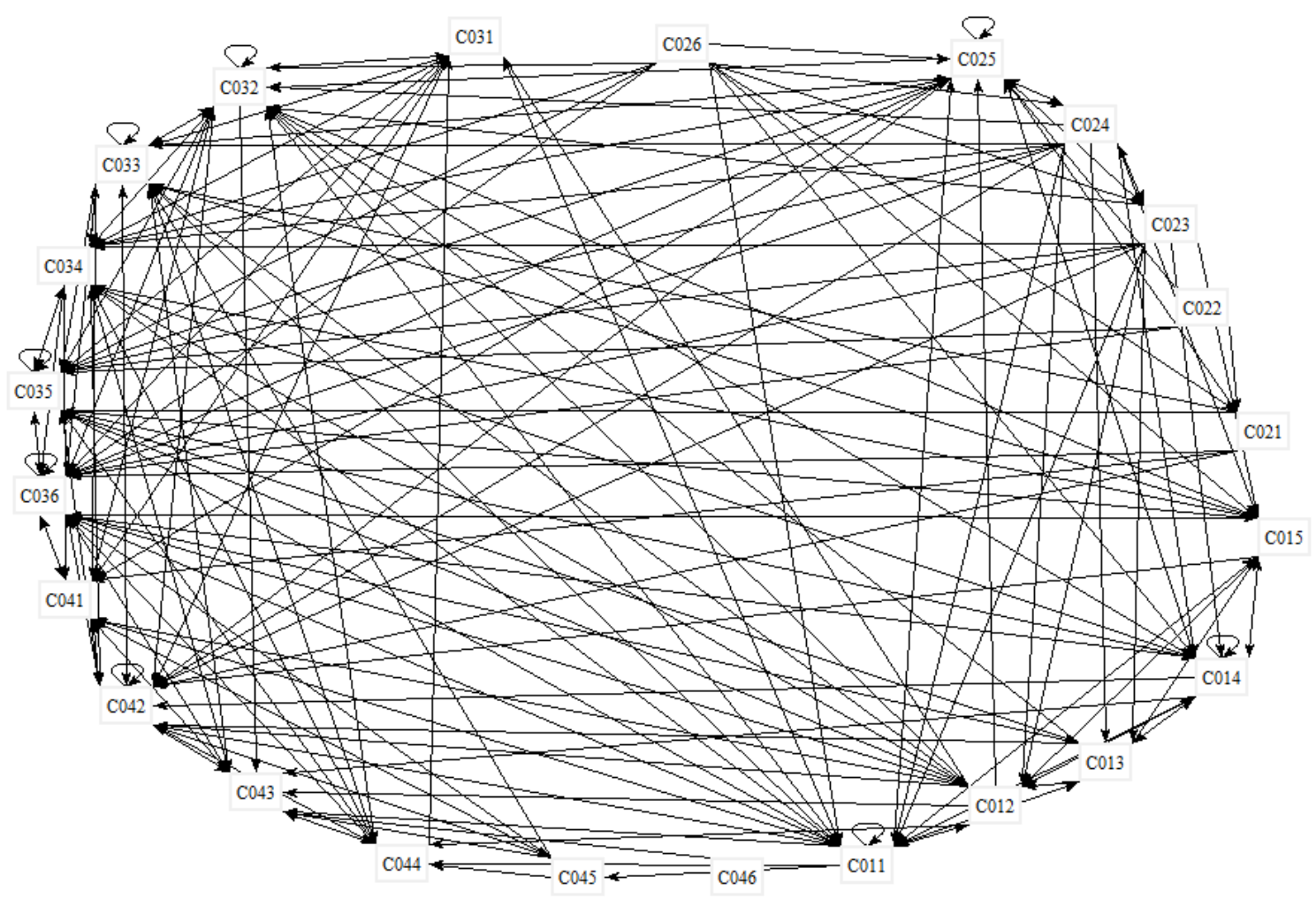

Diagram 4. The Impact Relationship Map (IRM) for Sub Impediments 


\section{Discussion}

This study aimed at discovering and clarifying the impediments of student engagement and their causal relationships by applying the Fuzzy Delphi method and the Fuzzy DEMATEL method. The results suggested four main impediments (university/institutional, environmental, family, and personal factors) interactively affect student engagement. This finding can be explained by Bandura's social cognitive theory which states that the amount of one's intellectual, psychological, and emotional investment in educational and learning activities is the product of dynamic interaction between personal, behavioral, and environmental factors.

DEMATEL analyses to define causal relationships between the criteria and sub-criteria demonstrated that there exist causal relationships among the four main impediments as well as among all the sub-criteria. It has also been clarified that out of these four factors, institutional (academic), environmental and family factors are influential factors, and personal and family factors are influenced factors. Regarding the degree of influence, the share of institutional factors is more than the environmental and family factors, and considering the degree of impressionability, the personal factors are higher than the family factors. These causal relationships can be explained as follows: university (institutional) and environmental factors directly and indirectly (as mediators) influence student engagement through personal and family factors and create opportunities and constraints for it.

Findings indicated that institutional factors have the greatest influence on other factors. This result is an endorsement for Kuh et al. (2008) student engagement definition which has highlighted the role of higher education institutions in creating engagement. Yorke \& Longden (2008) also considered disengagement mostly as the consequence of inner environments (intra-university) such as poor quality of teaching, and outer environment factors such as financial problems and student employment. This study demonstrated that the poor quality of teaching, inadequate facilities of classroom and institution, as well as Non-applicable material and curriculum are the first three critical impediments for student engagement considering the degree of their influence on other factors. All three factors are interrelated as well. Explaining the findings, we can say that teachers as the most critical actors of the learning and teaching scene and the engineers of students' intellectual software shape students' interests, perceptions, and dispositions. These tendencies and attitudes, in turn, can affect student engagement. Considering that the non-applicability of the curriculum with a high impact on other factors is also an important obstacle to academic excitement, teachers can resolve curriculum deficiencies and shortcomings through their quality teaching including using active teaching methods, designing meaningful, challenging and attractive learning activities, setting high-performance expectations for students, providing clear, precise and timely feedbacks, creating a supportive learning atmosphere as well as relating the curriculum with the real world., They can increase enthusiasm and eagerness in students through linking the classes with the real world and creating authentic learning, and play as a catalyst in transition from the classroom to the world of work. That is to say that the closer the curriculum is to students' personal and occupational experiences (Kahu, Stephen, Leach, \& Zepke, 2015), the more likely they are to be employable, the less concerned they will be about their career future, and the more engaged they will be. On the one hand, enriching learning experiences by providing authentic learning opportunities can help students to believe in their ability to achieve better job opportunities and a better life in the future as well. The students who believe in their abilities and are more optimistic and hopeful about the future would benefit a high level of academic engagement (Bandura, 2006).

Among the institution factors, insufficient and poor facilities are one of the most critical impediments since it is the second most influential factors on other factors. Poor classroom and institution facilities cause students to become passive spectators rather than active actors. How well universities allocate resources to facilities and services to accelerate and facilitate student learning is a vital factor in student engagement (Kuh, 2001 cited in Wolf, Kelly, and Kinzie, 2009). As the findings show student perceptions of institution rules and regulations (rigidity/ flexibility and /constraining/facilitating) and class time-tabling are one of the effects of student engagement. Providing the facilities to enrich student learning experiences and improve the quality of teaching, along with creating a student-friendly supportive environment with a flexible schedule (Bryson, 2010) make the campus a pleasant place for students so that they feel a connection, a sense of belonging, and identity with the university, and tend to spend more time and energy doing activities related to the institution.

Following the institution (university) factors, the most influential factors are environmental factors. According to the findings, the spread of credentialism in society is recognized as one of the impediments for student engagement that affects many other factors. Social phenomena of excessive reliance on academic degrees for job placement and job promotion make university volunteers enter universities with a passion for degrees rather than meaningful and deep learning. In this condition, students may seemingly involve in educational activities; but instead of authentic engagement (meaningful learning and hardworking in the face of difficulties), they would content themselves ritual 
compliance or ritual engagement (Schlechty, 2002) and do their minimum to earn a grade and degree. However, the damages caused by ritual engagement are much more than the damage caused by disengagement. It is to say that although we encounter the waste of resources in both cases (disengagement and ritual engagement) but the loss of disengagement that leads to leaving school is less than artificial engagement, continuing to study and graduation without the required competencies. Because this process, in turn, leads to the degradation of the value of academic status and degrees as well as distrust in educated people's capabilities.

Based on the findings, one of the environmental factors hindering engagement is the lack of relationship between education and income as well as unemployment of university alumni. Based on the expectancy-value theory (Lent, Brown, Sheu, Schmidt, Brenner, \& Gloster, et al., 2005), If students find that the materials they learn and their academic success lead to remarkable results such as better job, higher income, higher social mobility, and social status, and greater well-being and welfare, and education in society is of great value, they will be more involved in learning activities and pursue their learning goals more earnestly and seriously.

These findings emphasize the fact that individuals may have a different approach towards learning and education due to different ecology, structure, and social and cultural values, distinctive philosophy and education systems, and generally in terms of the geography of thought (Nisbett, 2003). Based on the theory of social cognitive career (Lent, Brown, and Hackett, 2000), the environment plays a vital role in students' academic and career aspirations and their interest in education. As Hyslop and Imperatore (2013 cited in Loera, Nakamoto, Oh, and Rueda 2013) have also mentioned, where university students perceive that there is no relationship between academic success and satisfactory and high-income job opportunities, their academic engagement would diminish. Therefore, in this case, they won't tend to continue their education or lose their engagement, endeavor, interest, and effort if they continue their education. Such a consequence can also arise out of students' insufficient competencies. As the results indicated the interaction between sub-factors (criteria), this can be related to the poor quality of teaching and the non-applicability of the curriculum. Hence, the revision of teaching methods and curriculum as well as combining job training and entrepreneurship with academic material can support the students' academic and job aspirations (Rowan-Kenyon, Perna, \& Swan, 2011 cited in Loera et al., 2013), employment, and job security in future. This can, in turn, lead to the elevation of student engagement.

Findings indicated that families are one of the influential and at the same time influenced factors (influenced by institutional and environmental factors). Family characteristics and conditions such as lack of financial support, lack of family support, family responsibilities especially for married students, family expectations, and requests of the family members and consequently mental preoccupations and physical and psychological problems are among those introduced by this study as impediments to student engagement.

With a constant increase in the costs of living and education (Scott-Clayton, 2012), and students' financial vulnerability due to insufficient income and assets, one of the most important sources of stress for students is financial problems (National Survey of Student Engagement, 2011). Part of this pressure can be alleviated through student loans and scholarship, and family financial support. Otherwise, students have to bear the burden of their college costs and will have to spend more hours working (Scott-Clayton, 2012). This interferes with their academic activities and makes them spend less time on their studies.

As the findings of interrelations among factors (impediments) indicate, the burden of life Kahu (2018), and the tension arising of academic and family responsibilities (Yorke, 2000) not only cause the mental busyness and a lack of time and consequently weak interaction with teachers and classmates, it also results in physical and mental problems. All of these lead to a decrease in academic engagement. As the Research findings indicate a relationship between financial aid to students and persistence (Leslie and Brinkman, 1987 cited in Fosnacht and Dong, 2013) and academic performance (Ross, Cleland, \& Macleod, 2006, cited in Fosnacht and Dong, 2013) providing such services like the child care centers, loans and scholarships, and part-time employment for students in college can increase student engagement.

\section{Conclusion}

This study sought to identify the barriers to student engagement and to find causal relationships among them. It can be concluded that student engagement is not a fixed feature, but it has a complex, dynamic, flexible, and changeable nature that would be subjected to fluctuations as a result of multiple factors (institutional, environmental, family, and personal). By identifying the four categories of factors and the interrelationships between them, this research considers student engagement as an ecosystem consisting of living factors/key players (student, teachers, society, family, and the larger society), their interdependence, and non-living components of the environment (expectations 
and facilities, resources, values, curriculum, policies, etc.). Accordingly, if an organism does not function properly, its failure would spread to other parts, and such a defective cycle may lead to the destruction of the whole ecosystem. Therefore, to enjoy the results and consequences of engagement, wise management of this ecosystem is a necessity. Since the engagement ecosystem consists of a network of players, factors, and facilitating and constraining elements, performing single-movement tasks doesn't work for its elevation. Rather, it requires that key actors of engagement namely the students themselves, teachers, social, economic, and political policy-makers, cultural engineers, community, and families with specialized but complementary capabilities work together in a synergic space to create value-added.

In a synergic atmosphere, the leaders can convert the student engagement brake into its engine by aligning and accompanying other inner and outer sections of higher education institutions. It requires the lean-agility of higher education institutions so that the speed of responsiveness would be greater than or equal to the rate of change in students and other primary and secondary stakeholders' demands and expectations $(\mathrm{R} \geq \mathrm{C})$. This study has examined the impediments for student engagement in general without relating it to engagement dimensions. Subsequent studies can address the effect of each impediment on the three dimensions of engagement.

This framework has developed theoretical knowledge in the field of influential factors of engagement as a cornerstone for future studies by a lens different from previous studies. By expanding our understanding of the barriers and interrelationships among them through DEMATEL, this framework helps academic leaders utilize it in policy and practice to fulfill the mission of universities in generating human capital.

\section{References}

Appleton, J. J., Christenson, S. L., \& Furlong, M. J. (2008). Student engagement with school: Critical conceptual and methodological issues of the construct. Psychology in the Schools, 45(5), 369-386. https://oi.org/10.1002/pits.20303

Bandura, A. (2006). Guide for constructing self-efficacy scales. In F. Pajares \& T. Urdan (Eds.), Self-efficacy beliefs of adolescents, 5, 307-337. Greenwich, CT: Information Age Publishing.

Benner, A. D., Graham, S., \& Mistry, R. S. (2008). Discerning direct and mediated effects of ecological structures and processes on adolescents' educational outcomes. Developmental Psychology, 44(3), 840-854. https://doi.org/10.1037/0012-1649.44.3.840

Chen, C. (2000). Extensions of the TOPSIS for group decision-making under fuzzy environment. Fuzzy Sets and Systems, 114(1). https://doi.org/10.1016/S0165-0114(97)00377-1

Chu, H., \& Hwang, G. (2008). A Delphi-based approach to developing expert systems with the cooperation of multiple experts. Expert Systems with Applications, 34, 2826-2840. https://doi.org/10.1016/j.eswa.2007.05.034

Cheng, C., \& Lin, Y. (2002). Evaluating the best main battle tank using fuzzy decision theory with linguistic criteria evaluation European. Journal of Operational Research, 142, 174-186. https://doi.org/10.1016/S0377-2217(01)00280-6

Eccles, J. S. (2007). Where are all the women? Gender differences in participation in physical science and engineering. In SJ Ceci, WM Williams (Eds.), why aren't more women in science. Top researchers debate the evidence (pp. 199-210). Washington, DC: American Psychological Association. https://doi.org/10.1037/11546-016

Eccles, J. S. (2005). Studying gender and ethnic differences in participation in math, physical science and information technology. New Directions for Child and Adolescent Development, 110, 7-14. https://doi.org/10.1002/cd.146

Eccles, J. S. (2011). Understanding educational and occupational choices. Journal of Social Issues, 67(3), 644-648. https://doi.org/10.1111/j.1540-4560.2011.01718.x

Fosnacht, K., \& Dong, Y. (2013). Financial stress and its impact on first-year students' college experience. St. Louis, MO: Association for the Study of Higher Education.

Fredricks, J. A., Filsecker, M., \& Lawson, M. A. (2016). Student engagement, context, and adjustment: Addressing definitional, measurement, and methodological issues. Learning and Instruction, 3, 14. https://doi.org/10.1016/j.learninstruc.2016.02.002

Fredricks, J., Blumenfeld, P., \& Paris, A. (2004). School engagement: Potential of the concept, state of the evidence. 
Review of Educational Research, 74(1), 59-109. https://doi.org/10.3102/00346543074001059

Harper, S. R., \& Quaye, S. J. (2009). Beyond sameness, with engagement and outcomes for all. In: student engagement in higher education. New York and London: Routledge.

Jang, H., Reeve, J., \& Deci, E. L. (2010). Engaging Students in Learning Activities: It is Not Autonomy Support or Structure but Autonomy Support and Structure. Journal of Educational Psychology, 102(3), 588-600. https://doi.org/10.1037/a0019682

Kahn, P. E. (2013). Theorising student engagement in higher education. British Educational Research Journal, 40(6), 1005-1018. https://doi.org/10.1002/berj.3121

Kahu, E. R., \& Nelson, K. (2018). Student engagement in the educational interface: understanding the mechanisms of student success. Higher Education Research \& Development, 37(1), 58-71. https://doi.org/10.1080/07294360.2017.1344197

Kahu, E. R. (2013). Framing student engagement in higher education. Studies in Higher Education, 38(5), 758-773. https://doi.org/10.1080/03075079.2011.598505

Kahu, E., Stephens, C., Leach, L., \& Zepke, N. (2014). Linking academic emotions and student engagement: Mature-aged distance students' transition to university. Journal of Further and Higher Education, 39(4), 481-497. https://doi.org/10.1080/0309877X.2014.895305

Kuh, G. D. (2001). Assessing What Really Matters to Student Learning: Inside the National Survey of Student Engagement. Change, 33(3), 10-17. https://doi.org/10.1080/00091380109601795

Kuh, G., Cruce, T., Shoup, R., Kinzie, J., \& Gonyea, R. (2008). Unmasking the effects of student engagement on first-year college grades and persistence. The Journal of Higher Education, 79(5), 540-563. https://doi.org/10.1353/jhe.0.0019

Lawson, M., \& Lawson, H. (2013). New conceptual frameworks for student engagement research, policy and practice. Review of Educational Research, 83(3), 432-479. https://doi.org/10.3102/0034654313480891

Lent, R. W., Brown, S. D., Sheu, H. B., Schmidt, J., Brenner, B. R., Gloster, C. S., Wilkins, G., Schmidt, L. C., Lyons, H., \& Treistman. (2005). Social cognitive predictors of academic interests and goals in engineering: Utility for women and students at historically Black universities. Journal of Counseling Psychology, 52, 84-92. https://doi.org/10.1037/0022-0167.52.1.84

Lent, R. W., Brown, S. D., \& Hackett, G. (2000). Contextual supports and barriers to career choice: A social cognitive analysis. Journal of Counseling Psychology, 47, 36-49. https://doi.org/10.1037/0022-0167.47.1.36

Li, Y., \& Lerner, R. M. (2011). Trajectories of school engagement during adolescence: implications for grades, depression, delinquency, and substance use. Developmental Psychology, 47, 233-347. https://doi.org/10.1037/a0021307

Lin, C. J., \& Wu, W. W. (2004). A fuzzy extension of the DEMATEL method for group decision making. European Journal of Operational Research, 156, 445-455.

Linstone, H. A., \& Turoff, M. (2002). The Delphi Method: Techniques and Application. Boston, MA: Addison-Wesley Publishing Co, Advanced Book Program.

Loera, G., Nakamoto, J., Oh, Y. J., \& Rueda, R. (2013). Factors that promote motivation and academic engagement in a career technical education context. Career \& Technical Education Research, 38(3), 173-190. https://doi.org/10.5328/cter38.3.173

Marks, H. M. (2000). Student Engagement in Instructional Activity: Patterns in the Elementary, Middle, and High School Years. American Educational Research Journal, 37, 153-184. http://dx.doi.org/10.3102/00028312037001153

National Survey of Student Engagement. (2011). Fostering student engagement campus wide-annual results 2011. Bloomington, IN: Indiana University Center for Postsecondary Research.

Nisbett, R. (2003). The Geography of Thought: How Asians and Westerners Think Differently...and Why. New York, NY: Free Press.

Salanova, M., Schaufeli, W., Martínez, I., \& Bresó, E. (2010). How obstacles and facilitators predict academic performance: The mediating role of study burnout and engagement. Anxiety, Stress and Coping, 23, 53-70. https://doi.org/10.1080/10615800802609965 
Schlechty, P. C. (2002). Working on the work an action plan for teachers, principals and superintendents (1st ed.). San Francisco, USA: Jossey Bass.

Scott-Clayton, J. (2012). What explains trends in labor supply among U.S. undergraduates, 1970-2009? NBER Working Paper, No. 1774. National Bureau of Economic Research, Cambridge, MA. https://doi.org/10.3386/w17744

Skinner, E. A., \& Pitzer, J. R. (2012). Developmental dynamics of student engagement, coping, and everyday resilience. In S. L. Christenson, A. L. Reschly, \& C. Wylie (Eds.), Handbook of Research on student engagement, 21-44. New York, NY: Springer. https://doi.org/10.1007/978-1-4614-2018-7_2

Stewart, E. B. (2008). School structural characteristics, student effort, peer associations, and parental involvement: The influence of school- and individual-level factors on academic achievement. Education and Urban Society, 40, 179-204. https://doi.org/10.1177/0013124507304167

Stipek, D. (2002). Good instruction is motivating. In A. Wigfield \& J. S. Eccles (Eds.), A Vol. in the educational psychology series. Development of achievement motivation, 309-332. Academic press. https://doi.org/10.1016/B978-012750053-9/50014-0

Tseng, M. L. (2009). A causal and effect decision making model of service quality expectation using grey-fuzzy DEMATEL approach. Expert Systems with Applications, 36, 7738-7748. https://doi.org/10.1016/j.eswa.2008.09.011

Trowler, V. (2010). Student engagement literature review. Retrieved from http://www.heacademy.ac.uk/assets/documents/studentengagement/StudentEngagementLiteratureReview.pdf

Wigfield, A. (1994). Expectancy-value theory of achievement motivation: A developmental perspective. Educational Psychology Review, 6(1), 49-78. https://doi.org/10.1007/BF02209024

Wolf-Wendel, L., Ward, K., \& Kinzie, J. (2009). A Tangled Web of Terms: The Overlap and Unique Contribution of Involvement, Engagement, and Integration to Understanding College Student Success. Journal of College Student Development, 50(4), 407-428. https://doi.org/10.1353/csd.0.0077

Yorke, M. (2006). Student engagement: Deep, surface or strategic? Paper presented at the Pacific Rim First Year in Higher Education Conference, Griffith University, Gold Coast Campus, Australia.

Yorke, M., \& Longden, B. (2008). The first year experience of higher education in the UK: Final report. Retrieved from https://www.heacademy.ac.uk/sites/default/files/fyefinalreport_1.pdf

Zepke, N. (2011). Non-institutional influences and student perceptions of success. Studies in Higher Education, 36(2), 227-242. https://doi.org/10.1080/03075070903545074

Zepke, N., \& Leach, L. (2010). Improving student engagement: Ten proposals for action. Active Learning in Higher Education, 11(3), 167-177. https://doi.org/10.1177/1469787410379680

Zepke, N., \& Leach, L. (2008). Improving student engagement in post-school setting: A synthesis of the literature. Paper presented at the NZARE conference, Palmerston North.

Zepke, N., Leach, L., \& Butler, P. (2010). Student engagement: What is it and what influences it? Retrieved from http://www.tlri.org.nz/sites/default/files/projects/9261-Introduction.pdf

\section{Copyrights}

Copyright for this article is retained by the author(s), with first publication rights granted to the journal.

This is an open-access article distributed under the terms and conditions of the Creative Commons Attribution license (http://creativecommons.org/licenses/by/4.0/). 